\title{
A Postulated Licensing Schedule for an Independent Spent Fuel
} Storage Installation

J.D. Ludwick

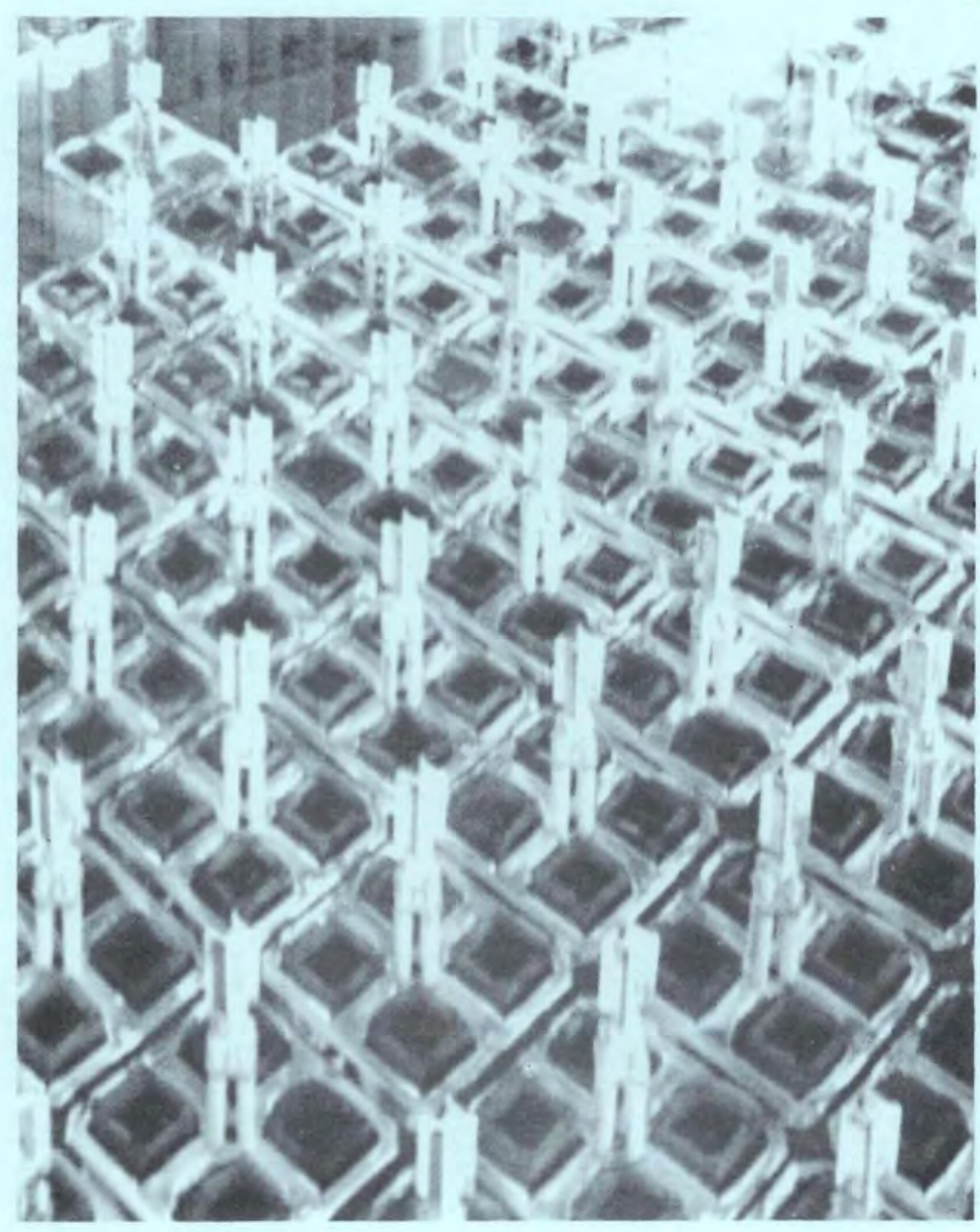

November 1982

Prepared for U.S. Department of Energy under Contract DE-AC06-76RLO 1830

Pacific Northwest Laboratory

Operated for the U.S. Department of Energy

by Battelle Memorial Institute 


\title{
DISCLAIMER
}

This report was prepared as an account of work sponsored by an agency of the United States Government. Neither the United States Government nor any agency thereof, nor any of their employees, makes any warranty, express or implied, or assumes any legal liability or responsibility for the accuracy, completeness, or usefulness of any information, apparatus, product, or process disclosed, or represents that its use would not infringe privately owned rights. Reference herein to any specific commercial product, process, or service by trade name, trademark, manufacturer, or otherwise, does not necessarily constitute or imply its endorsement, recommendation, or favoring by the United States Government or any agency thereof. The views and opinions of authors expressed herein do not necessarily state cr reflect those of the United States Government or any agency thereof.

\author{
PACIFIC NORTHWEST I.ABORATORY \\ operated by \\ BATTELLE \\ for the \\ UNITED STATES DEPARTMENT OF ENERGY \\ under Contract DE-AC06-76RLO 1830
}

\begin{tabular}{|c|c|}
\hline \multicolumn{2}{|c|}{ Printed in the United States of America } \\
\hline \multicolumn{2}{|c|}{ Available from } \\
\hline \multicolumn{2}{|c|}{ National Technical Information Service } \\
\hline \multicolumn{2}{|c|}{ United States Department of Commerce } \\
\hline \multirow{2}{*}{\multicolumn{2}{|c|}{$\begin{array}{c}5285 \text { Port Royal Road } \\
\text { Springfield, Virginia } 22151\end{array}$}} \\
\hline & \\
\hline \multirow{2}{*}{\multicolumn{2}{|c|}{$\begin{array}{l}\text { NTIS Price Codes } \\
\text { Microfiche A01 }\end{array}$}} \\
\hline & \\
\hline \multicolumn{2}{|c|}{ Printed Copy } \\
\hline & Price \\
\hline Pages & Codes \\
\hline $001-025$ & $\mathrm{~A} 02$ \\
\hline 026-050 & A03 \\
\hline 051-075 & A04 \\
\hline $076-100$ & A05 \\
\hline $101-125$ & A06 \\
\hline $126-150$ & $\mathrm{~A} 07$ \\
\hline $151-175$ & A08 \\
\hline $176-200$ & A09 \\
\hline $201-225$ & A 010 \\
\hline $226-250$ & A011 \\
\hline $251-275$ & A 012 \\
\hline $276-300$ & A013 \\
\hline
\end{tabular}


PNL-4498

UC-85

\begin{abstract}
A POSTULATED LICENSING SCHEDULE FOR AN INDEPENDENT SPENT FUEL STORAGE INSTALLATION
\end{abstract}

J. D. Ludwick

November 1982

Prepared for the U.S. Department of Energy under Contract DE-AC06-76RLO 1830

Pacific Northwest Laboratory

Richland, Washington 



\section{SUMMARY}

A review of licensing requirements, processes, and anticipated actions for independent spent fuel storage installations (ISFSIs) was conducted in order to develop an estimated schedule and sequence of events for licensing a new ISFSI. This estimate will be useful to potential ISFSI owners in planning for the licensing of their facilities.

It is concluded that, although many uncertainties exist with respect to such things as legal appeals, about 29 months are estimated to elapse between license application and license issuance for an ISFSI. This estimate is in reasonable agreement with a previous time estimate for licensing an ISFSI, and, taking into account the special circumstances involved, with the actual licensing schedule for the GE-Morris ISFSI. However, individual portions of the licensing schedule from each case studied sometimes vary significantly. 



\section{CONTENTS}

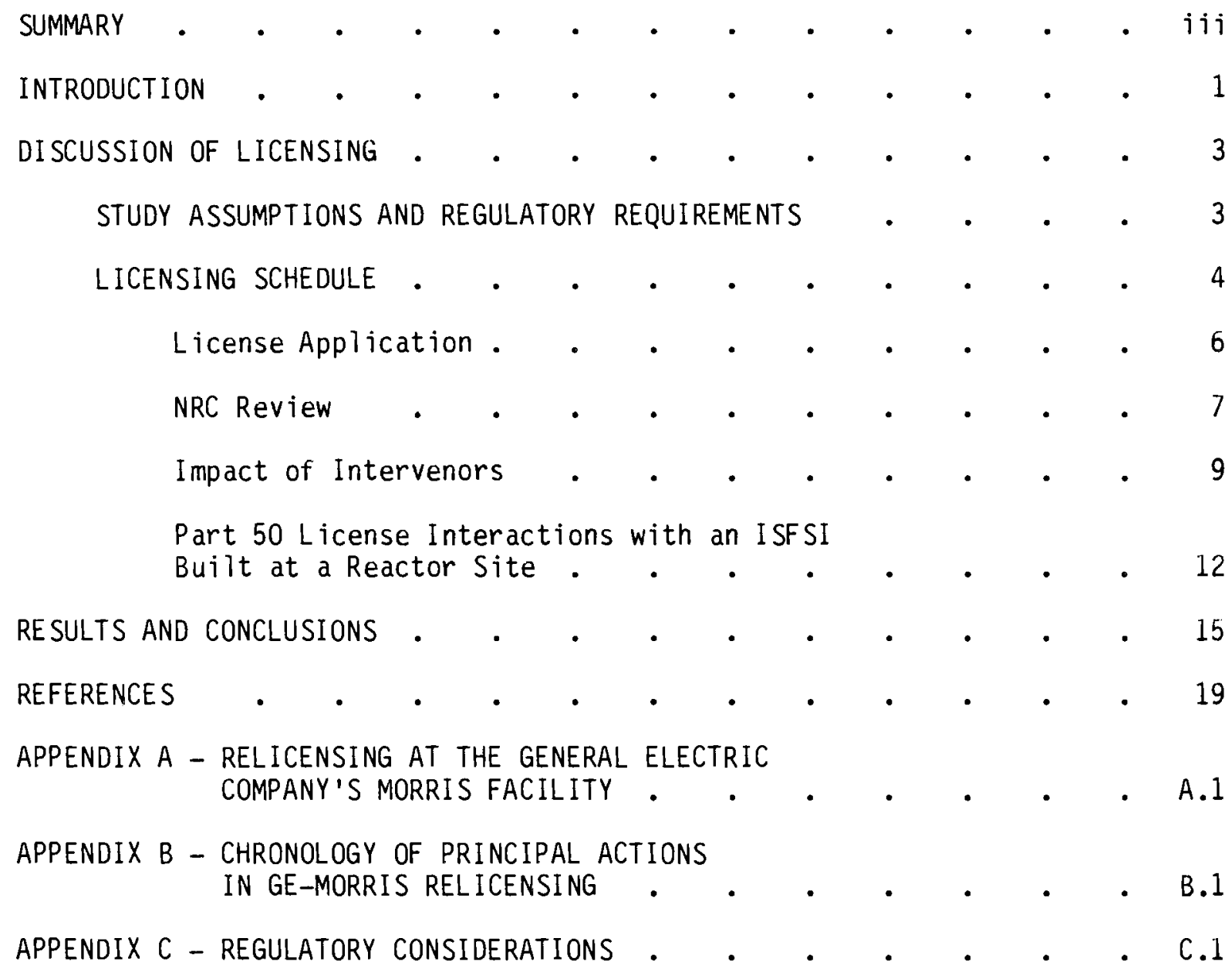




\section{FIGURES}

1 Estimated Schedule and Sequence of Events During Licensing for an ISFSI

2 A Comparison of Major Licensing Activities at Morris with Those Postulated for an Away-From-Reactor, Spent Fuel Storage Facility

\section{TABLES}

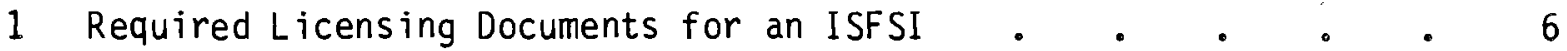

2 Criteria and Pertinent Documents Evaluated During the NRC

A.I Chronology of Relicensing Events at the GE-Morris

Facility 
INTRODUCTION

Many utilities that operate nuclear power plants are concerned about the accumulation of spent fuel in their plant storage pools. As these "in-house" storage areas fill to near capacity, serious consideration is being given to the construction of independent spent fuel storage installations (ISFSIs) on the nuclear power plant sites to provide adequate spent fuel storage capacity for the foreseeable future.

The NRC Commissioners have stated that spent fuel from power reactors is high-level waste, for the purposes of Section 202(3) of the Energy Reorganization Act. (1) Thus, a commercially operated ISFSI or one operated by the Department of Energy must be licensed by the NRC. Effective December 1980, the NRC added Part $72^{(2)}$ to Title 10 of the Code of Federal Regulations (10 CFR 72) to cover the specific licensing requirements for the storage of spent fuel in an ISFSI. Recently, the first ISFSI license was issued under this part of the code. (3) This action was for the license renewal at the General Electric Co.'s Morris Operation.

At this time, it is anticipated that many of the ISFSIs built will be in conjunction with existing reactor facilities; therefore, it should be recognized that locating an ISFSI on a nuclear power plant site will likely require an amendment to the Part 50 license to take into account possible interaction with the ISFSI.

The purpose of this study is to review the requirements and processes for licensing a new ISFSI and to postulate a schedule and sequence of events that potential ISFSI owners may encounter during licensing proceedings. This review and schedule information is anticipated to be useful to potential ISFSI owners in planning for the licensing of their facilities.

This study is based on certain assumptions and on the regulatory requirements in effect at this time. In the main body of this study, the impacts of several factors on the postulated schedule are considered. These factors include:

- license application

- NRC review of the license application 
- the intervenor process and the administrative court proceedings

- Part 50 license interactions with an ISFSI built at a reactor site.

The schedule and contributing activities postulated in this study are then compared both with those actually needed during the Morris proceedings and with those postulated in a similar study by Gray. (4)

Additional information used to derive the postulated ISFSI licensing schedule is found in the appendixes. Appendix A describes the history and the events that led to the relicensing of the GE-Morris ISFSI. Appendix $B$ is a chronology of the principal actions in the GE-Morris ISFSI relicensing, and Appendix $C$ contains a list of regulatory documents that govern ISFSI 1 icensing. 


\section{DISCUSSION OF LICENSING}

In order to estimate the time required to license an ISFSI, a number of assumptions were made. In addition, it was necessary to assess the impacts of the regulatory and administrative processes on the schedule. These assumptions and impacts are discussed in this section.

STUDY ASSUMPTIONS AND REGULATORY REQUIREMENTS

The assumptions listed below were used to make estimates of the time necessary for each licensing step or process. The overall licensing schedule is the result of the orderly integration of the individual processes and the time necessary to complete each of them.

1. The necessary licensing steps are derived from 10 CFR Part 2, "Rules of Practice for Domestic Licensing Proceedings." (5)

2. It is assumed that at least one outside entity will petition for and obtain intervenor status based upon provisions included in $10 \mathrm{CFR}$ Part 2.104, 2.105, and 72.34.

3. The original application submitted to the NRC is judged to be reasonably complete so as to allow early posting of action in the Docket (10 CFR Part 2.101(a)(3) and 2.702).

4. The estimated length of time needed for specific steps necessary during the proceedings is arrived at by considering the following:

a) Mandated by 10 CFR Part 2 or Part 72

b) The time required for similar processes to take place during licensing proceedings for the GE-Morris ISFSI, as shown in Appendix A

c) Estimated from discussions with NRC and GE personnel involved in the litigation of the first Part 72 licensing proceedings.

5. The time for normal additions or amendments and approval after the review period. 
A summary of regulations, guides and other standards that pertain to ISFSI licensing is presented in Appendix $C$. The impacts of regulatory requirements on the licensing schedule are discussed in the following subsections. These regulatory requirements effect the schedule throughout the licensing proceedings; however, this effect is rather clearly defined and schedule estimates for different ISFSIs are not expected to vary significantly because of these requirements.

\section{LICENSING SCHEDULE}

Filing of a license application with the Director, Division of Fuel Cycle and Material Safety, Office of Nuclear Material Safety and Safeguards (NMSS), U.S. NRC, is the first step in the licensing procedure. ISFSIs that require amendments to existing Part 50 licenses as part of their application also involve the Office of Nuclear Reactor Regulations (NRR). The procedures are governed by the Rules of Practice for Domestic Licensing Proceedings, 10 CFR Part 2.101 and 2.701, and the application form and content requirements are defined in the preceding subsection. The NRC will review the tendered license application for completeness and make it available for public inspection. Within 30 to 60 days, the acceptability of the license application will be determined and a docket number will be assigned to the application (2.101). This time interval and those that succeed it due to the necessary licensing actions are shown in Figure 1.

According to Part 2.102(b), the docketed application will be referred to the Advisory Committee on Reactor Safeguards (ACRS). This referral procedure was not followed in the Morris case nor will it be implemented in similar ISF SI licensing cases, according to discussions with the NRC. However, the application will be referred to the Commissioners who, in turn, will decide if ACRS referral is necessary. When the storage installation is located at a reactor site and an amendment to Part 50 is involved in the application, this referral is considered likely. In this report, it is postulated that the NRC

(a) Title 10, Part 2, Section 2.101, Code of Federal Regulations. 
Time (Months)

Proces 5

License Application to NRC $(2.101$, (a) 2.701, 72 Part B)

HRC Determination of Acceptability \& Completeness [2.101(2)]

Docket and Federal Register (2.104, $2.105,72.34$ )

Publ ic Notice of Proposed Action (2.102).

ACRS Prepares Report $(2.102)^{(d)}$

NRC NMSS Staff Review, EIA and SER (2.102)

NRC, MRR Staff Review (50.90)

Issue of Part 50 License Amendment (50.91)

Petitions to Intervene $(2.714,2.104)$

ASLB Established (2.704)

Applicant and NRC File Answers to Petitions [2.714(c)]

ASLB Rules on Petitions to Intervene $(2.714,2.715)$

Denied Petitioners Appeal [2.714a]

ASLAB Considers Appeal

ASLB Sets Date of Special Pre-Hearing Conference

Federal Register Publication of Hearing

Preparations for the Special Prehearing Conference

Special Pre-Hearing Conference (2.751a).

Litigations on Amended Contentions, Responses to Petitions

ASLB Rules on Contentions, Establishes Schedule for Discovery

Discovery (2.740). ASLB Notice of Disposition and Request for Documents to Support Contentions

ASLB Sets Pre-Hearing Conference Schedule

Preparations for Pre-Hearing Conference [2.752(a)]

Prehearing Conference (2.752)

Hearings

Proposed Findings and Conclusions (2.754)

Considerations of ASLB

Final Decision by ASLB

Review Decision by ASLAB and appeals (Part 2, Appendix B, 2.785)

Review Decision and Appeals by Conmissioners (Part 2, Appendix A, 2.764,2.786)

Issue of Part 72 ISFSI License

(a) 10 CFR Part 2.101.

b) Indicates a single event or a day or two period.

(d) The commission, at its option, may direct that the license application be reviewed by the ACRS.

\section{FIGURE 1. Estimated Schedule and Sequence of Events During Licensing for an ISFSI}


will refer the docketed application to the ACRS for their review and that the ACRS review will be included in the application record (Part 2.102). No impact on the length of schedule shown in Figure 1 is apparent from this decision because the items to be reviewed by the ACRS are perceived to be limited in scope and are anticipated to be resolved concurrent with the necessary NRC staff review process. In addition, after docketing, a notice will be published in the Federal Register announcing docketing and a notice of hearing in accordance with Part 2.104 or a notice of proposed action in accordance with Part 2.105. A hearing may not be held until 30 days following notice and publication in the Federal Register (Part 72.34).

Details of the processes involved are discussed in the following subsections.

License Application

The form and contents of license application are specified in Subpart $B$ of Part 72. The documentation required to be submitted with the license application is shown in Table 1. The NRC will review the application to determine if it is complete before the application is docketed and any other licensing actions can be taken.

TABLE 1. Required Licensing Documents for an ISFSI

10 CFR

Part

72.14

72.15

72.18

72.19

72.20

72.80

72.81

72.82

72.83
Document

License Application

Safety Analysis Report

Decommissioning $\mathrm{Pl}$ an

Emergency $\mathrm{P}$ lan

Environmental Report

Quality Assurance Program

Physical Security Plan

Design for Physical Protection

Safeguards Contingency Plan
No. of

Copies

25

70

25

25

150

25

10

10

10 
NRC Review

After docketing, the NRC will continue to review the license application and will establish a schedule for its review by their staff (Part 2.102). The criteria and pertinent documents that are evaluated during the NRC staff review are shown in Table 2. Interactions between the NRC and the Applicant can be expected frequently during this period. Examples of the subject matter discussed in these interactions and the time consumed in their resolution can be derived from the experience of GE during similar proceedings for the Morris operation. A chronology of these interactions is included in Appendix B. In the GE proceedings, about 17 months elapsed between license application and the time all questions ended that were pertinent to the original application for license renewal. Based upon discussions with personnel at the GE Morris facility, the review process was perceived to be complete at that time. Then, with the issuance of the new Part 72 of 10 CFR, the NRC requested that the license application be amended to conform to this new Part. Thereafter, 7 months were required to complete the review and issue the Safety Evaluation Report. (6) In essence, the NRC had conducted two reviews during the 24-month elapsed interval since license application. It is too optimistic to expect that subsequent license applications can be reviewed in as short a period as 7 months, since the NRC obviously had the benefit of the previous 17 months of input in the Morris case. However, it is also too pessimistic to suggest that 17 months would be required for the review, since this was a first-time effort on their part. These time intervals would appear to be the lower and upper boundaries that an applicant can anticipate for the NRC review process during ISFSI licensing. The 7-month interval represents the licensing of a familiar, well-established, previously reviewed design, while the 17-month interval represents the review process involving significant unfamiliar technology.

Recent discussions with the NRC indicate that their expectations for the duration of the ISFSI application review process is between 12 and 15 months. Based upon the many unknown aspects of applications review (e.g., staff availability, scheduling, conflicts with other types of license applications, NRC response to intervenors, etc.), one is hesitant to suggest that the 


\section{TABLE 2. Criteria and Pertinent Documents Evaluated During the NRC Staff Review of the ISFSI Licensing Application}

Criteria

- The application meets the standards and requirements of the Atomic Energy Act of 1954, as amended (ACt), and the Commission's regulations set forth in 10 CFR Chapter I

- The facility will operate in conformity with the application, the provisions of the Act, and the rules and regulations of the Commission

- The license complies with the siting factors enunciated in 10 CFR Part 72 , Subpart E

- If on the site of a nuclear power plant or other licensed activity or facility the ISFSI would not pose an undue risk to the safe operation of the power plant or facility

- The licensee's general design criteria complies with 10 CFR Part 72, Subpart F. An ISFSI would have to be designed to accommodate the types of spent fuel to be stored, and any restrictions of fuel types would be a subject of license conditions

- The licensee is qualified by reason of training and experience to conduct the operation covered by the regulation in 10 CFR Part 72

- The licensee's operating procedures to protect health and to minimize danger to life and property are adequate

- The licensee is financially qualified to engage in the activities in accordance with the regulations in 10 CFR Part 72

- The licensee's quality assurance plan complies with 10 CFR Part 72, Subpart G

- The licensee's physical protection provisions comply with 10 CFR Part 72 , Subpart H

- The licensee's personnel training program complies with 10 CFR Part 72 , Subpart I

- The licensee's decommissioning plan and its financing pursuant to Part 72.18 provide reasonable assurance that the decontamination and decommissioning at the end of its useful life will provide adequate protection to the health and safety of the public

- The licensee's emergency plan complies with Part 72.19

- There is reasonable assurance (a) that the activities authorized by the license can cont inue to be conducted without endangering the health and safety of the public, and (b) that such activities will continue to be conducted in compliance with the regulations of the Commission set forth in 10 CFR Chapter I

- The renewal of this license will not be inimical to the common defense and security or to the health and safety of the public

- The applicable provisions of 10 CFR Part 170 have been satisfied.

\section{Pertinent Documents}

- (a) Safety Analys is Report that complies with 10 CFR Part 7?.15 which is used as bas is for the Safety Evaluation Report (SER) issued by the NRC, and (b) Environmental Report (10 CFR Part 72.20) which meets the requirements of 10 CFR Part 51 and which is used as basis for the Environmental Impact Appraisal (EIA) issued by the NRC. 
process will be complete in less than the 12 months suggested as a minimum by the NRC. This is in agreement with the mean of the time extremes derived for the Morris case and is used in Figure 1 as the impact to overall schedule from the NRC review process for an application for ISFSI license. Should the NRC review require additional time, it appears that this review will not affect the overall licensing schedule because it will take place concurrent with intervenor litigations.

The end result of the NRC review process is the publication of an Environmental Impact Appraisal (EIA) based on the applicant's Environmental Report, and a Safety Evaluation Report (SER) based on the applicant's Safety Analysis Report. The EIA is issued first, in order to be available to the public at least 15 days prior to the time of any relevant hearing (Part 51.52). Providing this is done in a timely manner, no additional impact to the schedule will result.

Impact of Intervenors

Pursuant to publication of the notice of hearing (Part 2.105), interested parties may request a hearing or file a written petition with the NRC for leave to intervene according to Part-2.714. A minimum of 30 days following publication of the notice is allocated to allow interested entities to respond (Part 2.104).

In this report, it is presumed that the license application is contested. Should this not be the case, the licensing schedule is essentially dependent on the NRC staff review, the ACRS report, and the Commissioners' review. At the end of these reviews, the NRC is empowered to issue the license (Part 2.105). (Based upon discussions with the NRC staff, the review process is estimated to require approximately 12 months and an additional 1 to 2 months for license issuance.)

An Atomic Safety and Licensing Board (ASLB) is convened (Part 2.704) to rule on requests and petitions under Parts 2.714 and 2.715 . The applicant and the NRC may file answers to the petitions and are granted 10 days and 15 days, respectively, to do so. 
It is presumed in this report that one entity is given leave to intervene. However, the other petitioners that are denied, as well as the applicant and the NRC, have rights of appeal. Appeals are made to the Atomic Safety and Licensing Appeal Board (ASLAB) within 10 days (Part 2.714a). Thereafter, interested parties have an additional 10 days to file briefs in support or in opposition to the appeal.

Based on the premise that the most formidable intervenor will dictate the schedule and that others will not significantly impact this schedule, it is reasonable to consider that the proceedings will continue with this single added entity under auspices of the ASLB. The ASLB issues a prehearing conference schedule and a notice thereof is published in the Federal Register.

The impact to the schedule from the intervenor shown in Figure 1 is based on experience during the Morris relicensing, as described in Appendix $A$, wherein the actual prehearing conference was held 5 months after its original posted schedule. During this time interval, the intervenors requested delays and submitted amended contentions while the applicant and the NRC submitted statements of position on intervenor contentions. The ASLB rules on all contentions, accepting some, denying others, and possibly adding questions of their own.

A period of time is then needed for each entity to formulate arguments in support of their individual positions with respect to the accepted contentions. Each entity may obtain information from the others regarding matters that are relevant to the proceedings. This is called "Discovery" (Part 2.740). (This portion of the Morris schedule was not typical of that to be expected at subsequent ISFSI licensing proceedings because of the unique impact issuance of 10 CFR Part 72 had in the Morris case. Schedule estimates given here are based on the prescribed regulatory processes.) The ASLB then sets another prehearing conference date within 60 days (Part 2.752) to consider 211 arguments and to establish procedures and designate witnesses at the upcoming hearings. Shortly thereafter, testimony, cross-examination and counter arguments are presented by each party at hearings conducted by the ASLB. These hearings, in which the applicant bears the burden of proof that he should be granted a license, are the culmination of the various preliminary 
and preparatory steps. (Comparable deliberations required 6 weeks in the Morris case.) Any party to these proceedings may, or if so directed, shall file proposed findings of fact (Part 2.754) at the end of these hearings. The NRC has up to 40 days to do so and this period is shown (in Figure 1) to take place during the deliberations of the ASLB. The ASLB then retires to consider all arguments, testimony, and any proposed findings. During the Morris proceedings, October 2, 1981, was the last day arguments were presented before the ASLB. Five months later, on March 2, 1982, a decision and order was issued by the ASLB granting motion for summary disposition of all contentions and arguments. Then, the licensing proceedings were remanded back to the NRC for action. Discussions with GE and NRC employees attending the Morris proceedings before the ASLB indicated that a considerable amount of written and oral testimony was presented and that it is to be expected in similar licensing proceedings in the future. They concluded that the 5-month deliberation period used by the ASLB was necessary in view of the material to be reviewed. For these reasons, a 5-month period was estimated for this process in this report.

If no exception is taken to the ASLB decision, this will constitute the final action of the NRC and the license may be issued 45 days after the date of the decision (Part 2.760(a)). At this time about 29 months have elapsed since license application. This time interval is extended slightly in Figure 1 because there are two review processes that must take place irrespective of any exceptions taken to the ASLB decisions. Part 2.764 of 10 CFR provides that, for a new ISFSI, the initial decision shall not become effective until reviewed by the Commissioners who may then authorize the Director of NMSS to issue an initial license. In addition, Appendix $B$ of 10 CFR Part 2 mandates that the ASLAB, on its own motion, review the license application. These concurrent processes are estimated to take about 2 months.

If exception is taken to the ASLB decision, 30 days are allowed for appeal (Part 2.762). However, at this point in the proceedings, issues to be appealed will have already been given comprehensive study by all parties. Consequently, appeals are expected to be decided within the framework of the existing schedule (Parts $2.785,2.786)$. 
Part 50 License Interactions with an ISFSI Built at a Reactor Site

The subject of Part 50 license amendments may arise from: 1) recognition of need by the licensee, 2) NRR review of licensee proposals, or 3) NRR review of license application from NMSS referral.

Discussions with personnel within the NRR indicate that the possibility of Part 50 license amendment should be addressed as early as possible to prevent such action from impacting upon the ISFSI schedule. The need for such an amendment may be evident to the licensee, in which case an application is made at the time of the request for ISFSI 1icense. If the need for an amendment is not clear, the licensee should submit information to the NRR concerning the possible effect of the ISFSI on the reactor and its operations. In this way, early consideration of the potential interactions are assured. The NRR would then resolve the uncertainties by either suggesting that a Part 50 amendment is in order or that the issues involved can be adequately addressed by the NMSS in Part 72 license proceedings. In addition, the NMSS, during their ISFSI license review, may refer specific issues, when they arise, to the NRR for consideration.

Some of the issues of concern to the NRR that result from locating an ISFSI at a reactor site include:

- Redefinition of the reactor site and the jurisdiction of each portion. The reactor licensee is presently responsible for everything on the site. Will there be an independent ISFSI owner? Will the utility set up a separate division or entity to operate the ISF SI?

- Construction activity. How will construction activity, such as excavation blasting, affect the reactor? Is there potential for damage to existing power lines, the reactor cooling water system or the cooling towers?

- Electrical power interactions. Will the ISFSI be subfed from the reactor, and will the ISFSI make use of excess reactor power?

- Will any facilities be jointly shared between the reactor and the ISFSI (e.g., stack, fuel handling, laundry, and steam)? 
- Responsibility for security at the ISFSI portion of the site.

- Radiation monitoring responsibility arouna the joint site.

- Do reactor personnel have duties associated with the ISFSI (i.e., reactor operator performing ISFSI control room functions)?

- Will spent fuel from other reactors be brought onsite for storage?

The schedule for NRR review will run concurrent with the NMSS review to the point where all construction modifications of the proposed ISFSI are identified. Then, review by the NRR will result in either an amendment of the Part 50 license or concurrence with the Part 72 license application process. Personnel at NRR indicated that as the need for added fuel storage arose, they would be fundamentally in support of the ISFSI and that licensing issues to be resolved under their jurisdiction are perceived to be minor.

When the need for an amendment to the Part 50 license is identified, the possibility exists that intervenors may complicate the license action. Based upon the premise that the amendment issues are minor, intervention is not considered to have a high probability, and if it occurs, it is perceived to be resolvable within the schedule shown. Although there is no precedent in this situation, speculation by the NRC indicates that intervenor hearings and arguments associated with Part 50 amendments before the ASLB may take place in conjunction with the Part 72 intervenor process. This would reinforce the view that no significant impact to the proposed Part 72 ISFSI license schedule shown in Figure 1 would result from the added need for a Part 50 license amendment. 


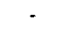


RESULTS AND CONCLUSIONS

Based on the governing processes discussed in this study and shown in Figure 1, an estimated 29 months will elapse between license application and license issuance. This estimate is consistent with the total time required for comparable licensing actions for the GE-Morris ISFSI. The licensing schedule for Morris encompassed 38 months; however, a unique 10-month delay was estimated to have resulted from the issuance of 10 CFR Part 72 during the licensing proceedings, as discussed in Appendix A. In a recent report, Gray estimated that about 32 months would be required during proceedings associated with obtaining an initial ISFSI license. ${ }^{(4)}$ Although several of the minor schedule details of the Gray report do not represent corresponding actions during the Morris proceedings, a comparison of the major processes that impact the schedule is useful. In Figure 2, the time estimated by Gray and the actual time during the Morris proceedings are compared, where possible. Almost all of the major licensing processes at Morris required more time than those estimated by Gray, and led to a longer schedule.

Two significant differences in licensing processes are apparent between these two schedules. First, deliberations by the ASLB after all arguments were presented required 5 months. No such process is noted by Gray. Discussions with GE and NRC personnel attending the Morris proceedings before the ASLB indicated that a considerable amount of testimony was presented and it is expected that like amounts of testimony will be presented in similar licensing proceedings in the future. GE and NRC staff concluded that the 5-month deliberation period by the ASLB was justified and should be expected in view of the material to be reviewed. Second, Gray estimated about 4 months would be required for appeals of the initial ASLB decision to the ASLAB. No corresponding actions were taken at Morris. Information from the Morris proceedings indicates that many issues were internally appealed and reviewed by the ASLB, thereby creating a degree of finalization to their decision (at least in the minds of the contestants).

It is apparent that there are many uncertainties involved in licensing of ISFSIs that impact the schedule. The most significant uncertainties are those 


DESIGN
PREPARE APPLICATION
LICENSINC
SUBMIT TO NRC
REVIEW FOR SUITABILITY
NRC OPENS DOCKET
STAFF TECHNICAL REVIEW
NOTICE OF PROPOSED ACTION
UNCONTESTED
LICENSE ISSUED
CONTESTED
INTERVENORS; CONTENTIONS
SPECIAL PREHEARING CONFERENCE
FINDINGS
DISCOVERY, PREPARATION
PREHEARINC CONFERENCE
BOARD RULING
INITIAL HEARINGS (DISCOVERY)
FINAL HEARINGS (SUMMATION)
INITIAL DECISION
APPEALS TO ASLAB
DELIBERATIONS OF THE ASLB
LICENSE ISSUED
CONSTRUCTION

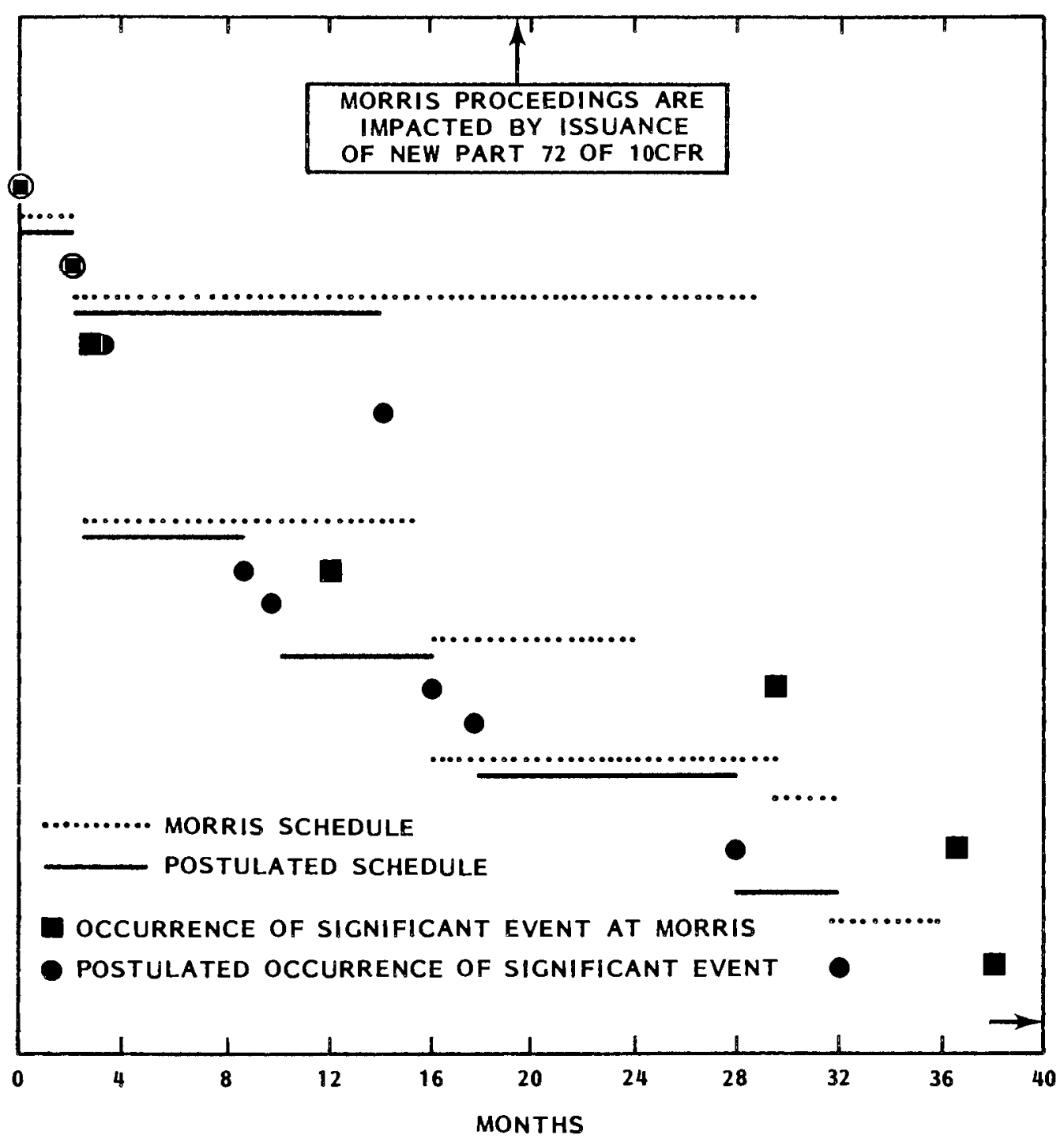

FIGURE 2. A Comparison of Major Licensing Activities at Morris with Those Postulated for an Away-From-Reactor, Spent Fuel Storage Facility $(4)$ 
associated with the legal appeal options available and the probability that any particular party to the licensing proceeding will avail themselves of these options. In view of these uncertainties, the difference between our estimate of 29 months and the 32 months estimated by Gray is not considered significant. However, the rationale used to arrive at the time estimates for individual licensing processes is sometimes significantly different. In this report, where the actual time duration could be distinguished for a specific licensing process (by historic reference to the Morris proceedings), this time was incorporated as the best estimate for the process. 



\section{REFERENCES}

1. Statement of Dr. Joseph R. Hendrie then Chairman of the U.S. Nuclear Regulatory Commission before the Committee on Energy and Natural Resources, U.S. Senate, May 10, 1979.

2. U.S. Nuclear Regulatory Commission. 1980. "Storage of Spent Fuel in an Independent Spent Fuel Storage Installation." U.S. Code of Federal Regulations, Title 10, Part 72 (10 CFR Part 72) . U.S. Government Printing Office, Washington, D.C.

3. Materials License No. SNM-2500, Morris Operation Facility, Grundy County, Illinois for General Electric Company, May 4, 1982.

4. P. L. Gray. August 1981. Licensing Schedule for Away-From-Reactor (AFR) Spent Fuel Storage Facilities. DP-1582, E. I. du Pont de Nemours \& Co., Savannah River Plant and Laboratory, Aiken, South Carolina.

5. U.S. Nuclear Regulatory Commission. 1979. "Rules of Practice for Domestic Licensing Proceedings." U.S. Code of Federal Regulations, Title 10, Part 2 (10 CFR Part 2). U.S. Government Printing Office, Washington, D.C.

6. U.S. Nuclear Regulatory Commission. July 1981. "Safety Evaluation Report Related to the Renewal of Materials License SNM-1265 for the Receipt, Storage, and Transfer of Spent Fuel Pursuant to 10 CFR Part 72." Morris Operation, General Electric Company, Docket No. 70-1308 and 72-1. NUREG-0709. 

APPENDIX A

RELICENSING AT THE GENERAL ELECTRIC COMPANY'S MORRIS FACILITY 
APPENDIX A

RELICENSING AT THE GENERAL ELECTRIC COMPANY'S MORRIS FACILITY

The Morris Plant, operated by the General Electric Company at Morris, Illinois, as an independent spent fuel storage installation (ISFSI), is the first facility of its kind to be licensed under 10 CFR Part 72 . Other potential ISFSI owners can benefit in their planning and preparation from the licensing experience at Morris. This appendix describes the licensing history and the events which led to the eventual licensing of the Morris facility under 10 CFR Part 72.

HISTORY

On October 6, 1967, the AEC reported on its review of General Electric Company's (GE) plans for construction of a spent fuel reprocessing facility at Morris, Illinois. A Provisional Construction Permit CPCS F-3 was issued on December 28, 1967. After construction, an application was submitted by GE to allow receipt and storage of light water reactor fuel at the facility. Materials license SNM-1265 was issued on December 27, 1971. At the same time, in connection with this action, the NRC issued an environmental evaluation (1) pending completion of the final environmental impact statement in December 1972. (2) In conjunction with termination of the construction permit on August 23, 1974, the spent fuel storage license was reissued for a 5-year term.

During February, 1975, GE submitted an amended application to increase the storage capacity to its present value (700 metric tons). After review and preparation of a Safety Evaluation Report (SER) (3) and an Environmental Impact Appraisal, (4) the amendment was issued on December 3, 1975.

By letter dated February 27, 1979, GE applied for a 20-year renewal of Materials License No. SNM-1265 pursuant to 10 CFR Parts 20, 40, and 70. The licensee submitted a Consolidated Safety Analys is Report dated January 1979 in support of the application. (5) Based on information supplied by personne? at the Morris facility and the Safety Evaluation Report, (6) a chronology of 
succeeding events related to license renewal has been developed ano is shown in Table A.1. The events that contributed to the 38-month period between license application and license renewal, shown in Table A.1, are discussed in the following paragraphs.

\section{LICENSE RENEWAL APPLICATION AT MORRIS OPERATIONS}

The license in effect at the time of application for renewal provided for operation until August 23, 1979. The regulations in effect at that time required that a license renewal application be filed at least 30 days prior to license expiration. (10 CFR Part 72 now requires at least a 2 -year advance application). Provided that the license application was submitted in a timely manner, the current license remains in effect during the period of time necessary to consider the application for renewal. The application for license renewal was made on February 27, 1979.

Three significant factors influenced the length of time that was consumed in considerations given to license renewal. These included:

- the NRC review process

- the public intervenor process

- implementation of new Part 72 of 10 CFR during licensing procedures.

It is difficult to resolve the influence of each factor upon the overall licensing time period since they often acted in concert to extend licensing proceedings.

\section{EARLY ACTIVITIES PRIOR TO ISSUANCE OF 10 CFR PART 72}

The intervenor process was initiated 3 months after license application. During the next 4 months, actions by all parties appear in conformance with expectations for filing and answering petitions including prompt scheduling of a special prehearing conference (September 17, 1979).

On that day, the state of Illinois requested a stay of the prehearing conference, and for some time thereafter, the NRC reported difficulties with the intervenors in setting up a firm schedule. The prehearing conference was actually held on February 29, 1980. One can only speculate on the necessity 


\section{TABLE A.1. Chronology of Relicensing Events at the GE-Morris Facility}

1972 - Materials License No. SNM-1265 issued December 27, 1971 for GE-Morris Operation

1974 - Materials License No. SNM-1265 reissued August 23, 1974 for five years for GE-Morris Operation

1979 - GE Application for 20-year renewal of Materials License No. SNM-1265 (February 27, 1979)

NRC requests added decommisstoning plan information; NRC inspects Morris Operation (March-April 1979) Federal Register Notice concerning license renewal (Aprtl 24, 1979)

GE submits decommissionting plan and decommissioning resources information and meets with NRC (April-May 1979)

State of Illinois and its citizens petition to intervene (May 21, 1979)

Atomic Safety and Licensing Board (ASLB) established June 12, 1979 and issues prehearing conference schedule ASLB rules on petition to intervene under Sections 2.714 and 2.715 of 10 CFR. Two intervenors are approved

(State of Illinots (State) and Rorem et al. (August 13, 1979)

Federal Register Notice of prehearing conference (August 20, 1979). GE submits emergency plan to NRC

State requests stay of prehearing conference (September 17, 1979)

NRC answers other intervenor petitions; meets with GE; informs ASLB of difficulty in meeting with intervenors

(October 1979)

NRC requests and GE responds with information on security training, safeguard contingency plan and assuring

decomissioning funding (November 1979)

GE and NRC submit statement of position on contentions of intervenors (November 20, 1979)

GE submits revtsed consolldated safety analys is report to NRC (December 17, 1979)

1980 - ASLB orders prehearing conference to be held on February 29, 1980 (January 17, 1980)

State submits amended contentions and petitions ASLB to dismiss licensing proceedings (February 14-15, 1980)

GE and NRC discuss amended contentions. NRC requests GE to provide added I1cense renewal information

(February 1980)

Prehearing conference (February 29, 1980)

State submits second set of amended contentions (March 20, 1980)

GE submits information to NRC on sabotage analysis, funds for decommisstoning, emergency plan, physical

securtty plan, and quality assurance plan reviston (March-Aprll 1980)

ASLB rules on contentions--accepting seven and adding three questions. All other intervenor petitions are rejected (June 4, 1980)

NRC issues Environmental Impact Appraisal (June 1980)

State requests more time for discovery (June 12, 1980) and motions for reconsideration of contentions deleted by ASLB (June 20, 1980)

ASLB rules on all reconsideration motions, issues notice of deposition and request for documents to support contentions (July 11, 1980)

(contd on next page) 


\section{TABLE A.1. (contd)}

1980 (contd)

GE, NRC and State respond to questions relating to discovery (July-August 1980)

NRC visits GE-Morris Operation for updating (July 31, 1980)

Manager GE-Morris Operation testiftes before ASLB (September 24, 1980)

NRC requests delay in proceedings due to new part 72 of 10 CFR (September 26, 1980); motion granted

(October 24, 1980)

NRC requests GE to amend Iicense application to conform with 10 CFR Part 72 and distributes part 72

(October, 1980)

GE proposes schedule for resumption of proceedings (November 11, 1980)

GE meets with NRC regarding effect of Part 72 on the license application (November 20, 1980)

ASLB grants stay of proceedings and issues new schedule (December 15, 1980)

1981 - NRC requests GE to submit additional information and moves to change schedule (January 31 - February 2, 1981)

State, Rorem, GE and NRC all request additional discovery and contentions for themselves and present arguments against others receiving same (Febuary-March 1981)

GE presents schedule for resumption of proceedings and requests rulings on all contentions (AprtI 7, 1981)

GE submtts information to NRC on fiscal condttion (April 9, 1981)

ASLB dentes all but one added contention (Aprtl 20, 1981)

NRC presents motion to dismiss Rorem et al. (May 21, 1981)

ASLB dtsmisses Rorem contentions and sets prehearing conference for July 23, 1981 (June 17-22, 1981); GE

requests delay to August 1981

GE repltes to NRC requests for informatton about emergency training, emergency planning and quality standards

(June 1981)

NRC Issues Safety Evaluation Report (July 1981)

NRC posts prehearing conference schedule (July 28, 1981)

Prehearing conference - GE, NRC and State present their arguments (August 14, 1981)

Manager GE-Morris Operation testifies, GE motions for summary disposition of all contentions, NRC motions for partial dismtssal of State contentions (August 28-September 2, 1981)

Cross-examination of witnesses and counter arguments presented by all part les (September 1981)

Final Arguments before ASLB (October 1981)

1982 - ASLB issues deciston and order for summary disposition and remands proceedings back to NRC (March 2, 1982)

NRC issues new 20-year Materials License No. SNM-2500 for GE-Morris Operation (May 4, 1982) 
of this 5-month delay. It is evident, however, from Table A.1 that the NRC review process was proceeding concurrently during this time interval and during the succeeding 3-1/2 months. On June 4, 1980, the Atomic Safety and Licensing Board (ASLB) ruled on all intervenors and their contentions (see Exhibit 1), and the NRC issued the Environmental Impact Appraisal.

The next 3-1/2 months were taken up in proceedings of the ASLB involving discovery with little interaction between the NRC and the licensee. At this time (October 1, 1980), 10 CFR Part 72 was approved and the NRC requested a delay in the proceedings. Based upon discussions with Morris personnel, the belief is held that, except for the issuance of new Part 72, the Safety Evaluation Report from the NRC would have been published by November 1980 , 8 months before its actual publication pursuant to 10 CFR Part 72 .

\section{ACTIVITIES AFTER ISSUANCE OF 10 CFR PART 72}

There are two major effects from issuance of new Part 72 upon the licensing proceedings. The NRC requested GE to amend its license application to conform to Part 72 and the intervenors took the opportunity to submit additional contentions and request further discovery. During November of 1980, GE proposed, before the ASLB, a schedule for resumption of proceedings. However, it was not until a similar request was made on April 1981 that the ASLB acted to resolve all added contentions and continue the proceedings. It is presumed that during this 6-month time interval the NRC was re-evaluating the amended license application. During May and June, 1981, the NRC requested and $G E$ responded with added information on a number of licensing topics. In July 1981, the NRC published the Safety Evaluation Report (SER) (NUREG-0709) related to the renewal of the materials license for the Morris facility. In mid-August 1981, the prehearing conference was held before the ASLB and all sides presented their arguments. After 6 weeks of testimony and cross-examination, the ASLB withdrew to consider the arguments. Five months later, on March 2, 1982, a decision was made to discard all intervenor contentions and remand the licensing proceedings back to the NRC.

Since the NRC had resolved all other licensing questions by their issuance of the EIA and SER, GE anticipated the issuance of the license 
30 days later. In this first-of-its-kind licensing action, caution prevailed and the license was issued 2 months later on May 4, 1982.

DISCUSSIONS

Although the intervenor process appropriately provides for the input of public concerns over licensing matters, it was used primarily as an opportunity to delay licensing proceedings in the Morris facility case. For example, only two entities presented arguments with sufficient substance to be given intervenor status, although several more took up time before the ASLB. Both intervenors used every possible opportunity to delay proceedings rather than present their arguments in a prompt and effective manner. Eventually one of the intervenors was dismissed for the continuing lack of proper judicial response to schedule and discovery. This dismissal took place over 2 years after petitioning for intervenor status.

There is some indication that an extra 8-month delay may have been introduced by the approval of 10 CFR Part 72 during the proceedings. This appears to be a conservative estimate, since adoption of this new regulation opened the door to added contentions and delays by the intervenors.

A little over 38 months was required to obtain the license renewal for the Morris facility. One is left to conjecture about the time interval to be expected in the absence of regulatory change. Based on the succession of events preceding issuance of Part 72 , in relation to many similar events that followed, it is estimated that an immediate 8- to 9-month delay occurred.

\section{REFERENCES}

1. Division of Materials Licensing. December 27, 1971. "Issuance of Source, Byproduct and Special Nuclear Licenses Prior to Completion of NEPA Environmental Review."

2. U.S. Atomic Energy Commission, Fuels and Materials, Directorate of Licensing. December 1972. "Final Environmental Statement Related to Operation of the Midwest Fuel Recovery Plant by the General Electric Co." Docket 50-268. 
3. U.S. Nuclear Regulatory Commission. December 3, 1975. "Safety Evaluation Report by the Division of Fuel Cycle and Material Safety Related to License Amendment for Material License No. SNM-1265, Morris Operation Facility, Grundy County, Illinois for General Electric Company, Docket No. 70-1308," NR-FM-001.

4. U.S. Nuclear Regulatory Commission. December 5, 1975. "Environmental Impact Appraisal by the Division of Fuel Cycle and Material Safety Related to License Amendment for Material License No. SNM-1265, Morr is Operation Facility, Grundy County, Illinois for General Electric Company, Docket No. 70-1308," NR-FM-002.

5. General Electric Company. January 1979. "Consolidated Safety Analysis Report for Morris Operation." NEDO-21326 C.

6. U.S. Nuclear Regulatory Commission. July 1981. "Safety Evaluation Report Related to the Renewal of Materials License SNM-1265 for the Receipt, Storage, and Transfer of Spent Fuel Pursuant to 10 CFR Part 72." Morris Operation, General Electric Company, Docket No. 70-1308 and 72-1, NUREG-0709.

7. P. L. Gray. August 1981. Licensing Schedule for Away-From-Reactor (AFR) Spent Fuel Storage Facilities. DP-1582, E. I. du Pont de Nemours \& Company, Savannah River Plant and Laboratory, Aiken, South Carolina. 


\section{EXHIBIT 1}

\section{STATE OF ILLINOIS CONTENTIONS}

The state of Illinois and private citizens residing in Illinois presented a number of contentions before the ASLB. Originally the ASLB accepted the validity of ten contentions and added a question of their own. During hearings involving clarification of contentions, one contention (\#6) was dismissed because neither the State nor any other intervenor would submit clarification. The contentions that were considered in the final ASLB decision are presented in summary form below.

1. The CSAR does not adequately describe:

a) Consequences of simultaneous accidental releases from the Drescen nuclear power plant and the Morris facility.

b) Risk and consequences of radioactive releases in excess of 10 CFR Part 20 for four different events:

- tornados

- coolant accidents

- sabotage

- earthquakes.

2. The physical security plan does not meet the requirements of 10 CFR Part 73 (CSAR does not provide enough protection against sabotage.).

3. The CSAR underestimates or does not state fully the health effects to personnel from occupational exposure to radiation in the following cases:

a) Total whole-body exposure for the projected life of the facility.

b) Total genetic impact.

c) Does not include tanks and pipes as sources of radiation exposure.

d) Does not account for additional radiation exposure from all anticipated activities.

e) Does not address the subject of an effective radiation monitoring program for the air. 
4. Deficiencies exist concerning decommissioning:
a) There is insufficient analyses of decommissioning costs ano decontamination factors.
b) There is insufficient assurance that GE will be financially capable of accomplishing the task.
c) There is no contingency plan to decommission in the event of premature plant shutdown.
d) There is no provision for continued care in the event of long-term storage of the facility.
e) The CSAR does not make the necessary financial arrangements as required by Parts 72.14 and 72.18 .

5. The emergency plan as described in the CSAR is inadequate because:
a) It does not specify emergency procedures for moving fuel offsite.
b) It should be supplemented to explain the plans for emergency transfer of fuel.
c) There are no references that demonstrate that the emergency plans are adequate.

6. Contention dismissed.

7. The NRC has an obligation, under NEPA, to issue an EIS. (They issued an EIA.)

8. The CSAR does not provide for the safe control of the facility under off-standard or accident conditions. It does not provide adequate personnel accessway.

9. The operator training and certification program is inadequate. It also fails to establish any minimum academic requirement or numerical, fail/pass, testing grade.

10. GE does not comply with Parts 72.16 and 72.33 with respect to the handing and storage of damaged spent fuel.

ASLB question to GE:

What activities are going to be performed under the license renewal? 


\section{.}


APPENDIX B

CHRONOLOGY OF PRINCIPAL ACTIONS IN GE-MORRIS RELICENSING 
APPENDIX B

CHRONOLOGY OF PRINCIPAL ACTIONS IN GE-MORRIS RELICENSING

Date

February 27, 1979

March 1, 1979

March 8, 1979

March 8, 1979

Apri1 4, 1979

Apri1 10, 1979

April 18, 1979

April 23, 1979

Apri1 24, 1979

May 2, 1979

May 8, 1979

May 14, 1979
Brief Description

Letter, D. M. Dawson/GE to R. E. Cunningham, (a) application for Renewal of Materials License SNM-1265

Letter, L. C. Rouse to D. M. Dawson/GE on Decommissioning Plan

Letter, D. M. Dawson/GE to R. E. Cunningham transmitting General Electric 1977 Annual Report

Letter, D. M. Dawson/GE to L. C. Rouse, status of stored fuel

Letter, D. M. Dawson/GE to R. E. Cunningham, response to questions, decommissioning plan for Morris Operation

Letter, L. C. Rouse to D. M. Dawson/GE amendment and reissue of Materials License No. SNM-1265 incorporating Materials License SNM-1281 and terminating SNM-1281 Amendment No. 7 attached

Letter, D. M. Dawson/GE to R. E. Cunningham, Revision B3, NED0-20969, Operating Experience - Irradiation Fuel Storage - Morris Operation; Environmental Monitoring Report for 1978

Letter, Davis to L. Zahn, Jr/GE, re March 27 and April 2-5, 1979 inspection

Letter, D. M. Dawson/GE to L. C. Rouse, current inventory of fuel stored at Morris

Letter, L. C. Rouse to D. M. Dawson/GE transmitting Federal Register Notice published April 24, 1979

Letter, D. M. Dawson/GE to L. C. Rouse with replacement page to letter DMD-316 dated April 24, 1979

Letter, Beaton/GE to R. E. Cunningham re Decommissioning Resources

(a) NRC personnel unless otherwise posted. 
Date

May 16, 1979

June 13, 1979

Ju1y 2, 1979

August 22, 1979

August 22, 1979

September 27, 1979

October 4, 1979

November 2, 1979

November 6, 1979

November 15, 1979

November 20, 1979

December 17, 1979

January 8, 1980
Brief Description

Letter, D. M. Dawson/GE to R. E. Cunningham re Decommissioning Plan - Morris Operation, ref. April 4, 1979 letter and Beaton's May 14 letter

Meeting regaraing proposed 1 icense amendment application to permit decontamination tests of BWR assemblies

Letter, D. M. Dawson/GE to L. C. Rouse, stored fuel status

Letter, GE to $F$. Empson, operating experience irradiated fuel storage NEDO-20969B2 Class 1, January 1979

Letter, D. M. Dawson/GE to R. E. Cunningham, Radiological Emergency Plan for Morris Operation NEDO-21894, dated June 1978

Letter, D. M. Dawson/GE to R. E. Cunningham re Dr. John E. Van Hoomissen replaces Lyle Zahn as Manager, Spent Fuel Services Operation

Meeting regarding possible additional work at Morris Operation

Letter, D. M. Dawson/GE to L. C. Rouse, status of stored fuel

Letter, McCorkle to D. M. Dawson/GE re review of revised Security Personnel Training and Qualification Plan arid revised Safeguards Contingency Plan

Letter, D. M. Dawson/GE to R. E. Cunningham, advance copy of Revisea Table 7-3, NEDO-21326C1

Letter, L. C. Rouse to D. M. Dawson/GE, provisions to assure necessary funds are available for decommissioning

Letter, D. M. Dawson/GE to R. E. Cunningham re Revision C1 NEDO 21326C, Consolidated Safety Analysis Report for Morris

Letter, D. M. Dawson/GE to L. C. Rouse, NRC status of stored fuel 
January 23, 1980

February 21, 1980

Letter, D. M. Dawson/GE to R. E. Cunningham re $2 / 21 / 80$ Discussion Outline Transmitting Document referenced in Amended Contentions submitted by state of Illinois Attorney General

February 27, 1980

Letter, D. M. Dawson/GE to R. E. Cunningham re Information for ORNL re Crane Details

February 28, 1980

March 3, 1980

Letter, L. C. Rouse to D. M. Dawson/GE requesting additional information re renewal

Letter, D. M. Dawson/GE to L. C. Rouse, status of stored fuel

March 11, 1980

Letter, Rogers/GE to R. E. Cunningham re NEDM-20482 (Reprint) Transmitting copy of above per telecon "Sabotage Analysis for Fuel Storage at Morris"

April 15, 1980

Letter, D. M. Dawson/GE to R. E. Cunningham General Emergency Plan for Morris Operation, NEDO-24784, February 1980

April 15, 1980

Letter, Bertram Wolfe to NRC, Funds for Decommissioning Morris Operation

April 25, 1980

Letter, D. M. Dawson/GE to R. E. Cunningham, Response to request for additional information: Renewal of Materials License SNM-1265 Attachment: Quality Assurance Plan Revision

May 1,1980

Letter, D. M. Dawson/GE to L. C. Rouse attaching table to show increase in inventory of fuel at GE Morris because of receipt of six PWR fuel bundles from San Onofre

May 16,1980

Letter, D. M. Dawson/GE to R. Burnett, Physical Security Plan - Morris Operation, NEDO-14507C4, December 1979: Notification of Change in Plan 
Date

June 6,1980

June 10,1980

June 12,1980

July 1,1980

July 2, 1980

July 31,1980

August 25, 1980

October 9, 1980

November 3, 1980

November 20, 1980

November 21, 1980

November 21,1980

January 19, 1981

January 30, 1981
Brief Description

Letter, D. M. Dawson/GE to R. E. Cunningham, on addition to pump room at Morris Operation

Meeting regarding GE January 23, 1979 amendment request

Letter, D. M. Dawson to R. E. Cunningham, revised amendment request regarding changes, tests, and experiments

Letter, D. M. Dawson/GE to R. E. Cunningham, letter on ages and average burnup for fuel stored at Morris operation

Letter, D. M. Dawson/GE to R. E. Cunningham, status of stored fuel

Site visit by A. T. Clark for updating

Letter, D. M. Dawson/GE to F. M. Empson, compressed air system at Morris Operation

Letter, D. M. Dawson/GE to L. C. Rouse, status of stored fue 1

Letter, D. M. Dawson to L. C. Rouse increasing inventory of fuel stored at GE Morris-replaces letter of October 9, 1980

Meeting regarding effect of 10 CFR Part 72 on renewal application

Letter, D. M. Dawson/GE to R. E. Cunningham re Rev. B4, Operating Experience Report - Irradiated Fuel Storage at Morris Operation, January 72 - December 7y, September 80, NED0-20969B

Letter, D. M. Dawson/GE to R. E. Cunningham re Intent to Pursue Application for Renewal of License

No. SNM-1265

Letter, D. M. Dawson/GE to L. C. Rouse, status of stored fuel

Letter, L. C. Rouse to D. M. Dawson/GE requesting additional information for application for renewal of License No. SNM-1265 
February 26, 1981

March 2, 1981

March 17, 1981

April 9, 1981

May 1, 1981

May 15,1981

June 5,1981

June 12,1981

June 18,1981

June 23, 1981
Brief Description

Letter, L. C. Rouse to D. M. Dawson/GE requesting additional information on their January 5 submittal

Letter, D. M. Dawson/GE to L. C. Rouse, status of stored fue 1

Letter, D. M. Dawson/GE to R. E. Cunningham, 1980 information on QA plan

Letter, D. M. Dawson/GE to R. E. Cunningham, 1980 Financial Information

Letter, Robert F. Burnett to D. M. Dawson/GE, transmitting physical protection license amenament

Letter, D. M. Dawson/GE to R. E. Cunningham, response to request on emergency training

Letter, L. C. Rouse to D. M. Dawson/GE request for additional information on emergency planning

Letter, D. M. Dawson/GE to R. E. Cunningham, response to request on emergency planning

Letter, L. C. Rouse to D. M. Dawson/GE, request for additional information on quality standards criteria

Letter, D. M. Dawson/GE to R. E. Cunningham, response to question on quality standards criteria 

APPENDIX C

REGULATORY CONSIDERATIONS 
APPENDIX C

REGULATORY CONSIDERATIONS

This appendix contains a brief list of regulations, regulatory guides and standards that govern the licensing of independent spent fuel storage installations.

REGULATIONS

10 CFR 2 - Rules of Practice for Domestic Licensing Proceedings

10 CFR 72 - Storage of Spent Fuel in an Independent Spent Fuel Storage Installation

\section{REGULATORY GUIDES}

3.44 - Standard Format and Content for the Safety Analysis Report to be included in a License Application for the Storage of Spent Fuel in an Independent Spent Fuel Storage Installation (Water-Basin Type)

3.48 - Standard Format and Content for the Safety Analys is Report for an ISFSI (dry storage type)

3.50 - Guidance on Preparing a License to Store Spent Fuel in an ISFSI

3.53 - Applicability of Existing Regulatory Guides to the Design and Operation of an ISFSI

The following are perceived to provide generic guidance for licensees:

1.8 Personnel Qualification and Training

1.16 Reporting of Operating Information

1.17 Protection of Nuclear Power Plants Against Industrial Sabotage

8.2 Guide for Administrative Practices in Radiation Monitoring

8.3 Film Badge Performance Criteria

8.4 Direct-Reading and Indirect-Reading Pocket Dosimeters

8.6 Standard Test Procedures for Geiger-Muller Counters

8.9 Acceptable Concepts, Models, Equations, and Assumptions for a Bioassay Program

8.10 Operating Philosophy for Maintaining Occupational Radiation Exposure As Low As Reasonably Achievable 
STANDARDS

ANS-57.7 - Design Criteria for an Independent Spent Fuel Storage Installation (Water-Pool Type)

ANS-2.19 - Guidelines for Establishing Site-Related Parameters for Site Selection and Design of an Independent Spent Fuel Storage Installation (Water-Pool Type)

ANSI Z88.20-1969 - Procedures for Respiratory Protection USBM-23, Respiratory Protective Services for Use in Atmospheres Containing Radioactive Materials 
DISTRIBUTION

No. of

Copies

OFFSITE

D. Stah 1

Battelle Columbus Laboratory $505 \mathrm{King}$ Avenue

Columbus, $\mathrm{OH} 43201$

3 DOE Office of Spent Fuel

Management and Reprocessing Systems

NE-40 GTN

Washington, DC 20545

ATTN: K. A. Klein

K. 0. Laughon

S. P. Schneider

2 Electric Power Research

Institute

P.0. Box 10412

Palo Alto, CA 94304

ATTN: R. W. Lambert

R. F. Williams

S. J. Beard

Exxon Nuclear Company, Inc.

2101 Horn Rapids Road

Richland, WA 99352

3 General Electric Company

Morris Operation

Morris, IL 60450

ATTN: K. Eggers

H. R. Strickler

E. E. Voiland

2 E. R. Johnson Associates, Inc. 11702 Bowman Green Drive

Reston, VA 22090

ATTN: E. R. Johnson

J. A. McBride
No. of

Copies

J. B. Moegling

Tennessee Valley Authority

403 Power Building

6 th and Market Streets

Chattanooga, TN 37402

M. Smith

Virginia Electric and Power Co.

P.0. Box 2666

Richmond, VA 23261

A. R. Hakl Westinghouse Electric Corp. P.0. Box 708

Mercury, NV 89023

G. A. Townes

Allied-General Nuclear Service P.0. Box 847

Barnwel1, SC 29812

108 DOE Technical Information Center

ONSITE

3 DOE Richland Operations office

P. A. Craig

H. E. Ransom

J. J. Schreiber

3 Rockwell Hanford Operations

G. A. Huff

R. E. Smith

File Copy

UNC/United Nuclear Industries

F. H. Bouse 
No. of

Copies

Hanford Engineering Development

Laboratory

R. L. Knecht

54 Pacific Northwest Laboratory

W. J. Bailey

G. H. Beeman

H. C. Burkholder

R. A. Clark

J. M. Creer

D. A. Dingee

R. M. Fleischman

J. F. Fletcher

M. D. Freshley

E. R. Gilbert

G. M. Holter

A. B. Johnson, Jr.

W. S. Kelly

R. C. Liikala

J. D. Ludwick (25)

H. D. Massey

J. L. McElroy

D. F. Newman

D. R. Payson

D. E. Rasmussen

R. I. Smith

M. K. White

L. D. Williams

Publishing Coordination (2)

Technical Information (5) 